\title{
Dust from the dark region in the western ablation zone of the Greenland ice sheet
}

\author{
I. G. M. Wientjes ${ }^{1}$, R. S. W. Van de Wal ${ }^{1}$, G. J. Reichart ${ }^{2,3}$, A. Sluijs ${ }^{4}$, and J. Oerlemans ${ }^{1}$ \\ ${ }^{1}$ Institute for Marine and Atmospheric research Utrecht (IMAU), Utrecht University, Princetonplein 5, \\ 3584 CC, Utrecht, The Netherlands \\ ${ }^{2}$ Department of Earth Sciences, Utrecht University, Budapestlaan 4, 3584 CD Utrecht, The Netherlands \\ ${ }^{3}$ Alfred Wegener Institute for Polar and Marine Research, Am Handelshafen 12, 27570, Bremerhaven, Germany \\ ${ }^{4}$ Biomarine Sciences, Institute of Environmental Biology, Utrecht University, Laboratory of Palaeobotany and Palynology, \\ Budapestlaan 4, 3584 CD Utrecht, The Netherlands
}

Received: 29 November 2010 - Published in The Cryosphere Discuss.: 10 December 2010

Revised: 1 July 2011 - Accepted: 4 July 2011 - Published: 22 July 2011

\begin{abstract}
A dark region tens of kilometres wide is located in the western ablation zone of the Greenland ice sheet. The dark appearance is caused by higher amounts of dust relative to the brighter surroundings. This dust has either been deposited recently or was brought to the surface by melting of outcropping ice. Because the resulting lower albedos may have a significant effect on melt rates, we analysed surface dust on the ice, also called cryoconite, from locations in the dark region as well as locations from the brighter surrounding reference ice with microscopic and geochemical techniques to unravel its composition and origin. We find that (part of) the material is derived from the outcropping ice, and that there is little difference between dust from the dark region and from the reference ice. The dust from the dark region seems enriched in trace and minor elements that are mainly present in the current atmosphere because of anthropogenic activity. This enrichment is probably caused by higher precipitation and lower melt rates in the dark region relative to the ice marginal zone. The rare earth elemental ratios of the investigated material are approximately the same for all sites and resemble Earth's average crust composition. Therefore, the cryoconite probably does not contain volcanic material. The mineralogical composition of the dust excludes Asian deserts, which are often found as provenance for glacial dust in ice cores, as source regions. Consequently, the outcropping dust likely has a more local origin. Finally, we find cyanobacteria and algae in the cryoconite. Total Organic Carbon accounts for up to 5 weight per cent
\end{abstract}

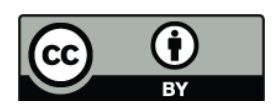

Correspondence to: I. G. M. Wientjes (i.g.m.wientjes@uu.nl) of the cryoconite from the dark region, whereas dust samples from the reference ice contain only $1 \%$ or less. This organic material is likely formed in situ. Because of their high light absorbency, cyanobacteria and the organic material they produce contribute significantly to the low albedo of the dark region.

\section{Introduction}

The western ablation zone of the Greenland ice sheet contains a region that appears darker (in visible band satellite imagery) than the surrounding ice (Fig. 1). This dark region is situated tens of kilometres from the margin and stretches from $65^{\circ} \mathrm{N}$ to $70^{\circ} \mathrm{N}$. The dark appearance implies a lower albedo and therefore an enhanced melt rate. Oerlemans and Vugts (1993) show that for the summer seasons of 1990 and 1991, the averaged albedo for a site in the dark region (S6) was around 0.41 , whereas the averaged albedo for a site in the brighter ice region (S5) was around 0.53. For recent years, the averaged summer albedo at S6 was mostly around $10 \%$ lower than at S5 (unpublished data). Unravelling the underlying processes that account for the low albedo is critical to determine the existence of this region. More knowledge about these causes will help to predict how this region will develop in the future, and how it will affect the mass balance of the Greenland ice sheet.

Accumulation of melt water at the surface could cause the observed dark region, since water might drain slowly due to the cold ice and the small surface slope (Van de Wal and Oerlemans, 1994; Knap and Oerlemans, 1996; Greuell, 2000). However, Wientjes and Oerlemans (2010) investigated the

Published by Copernicus Publications on behalf of the European Geosciences Union. 


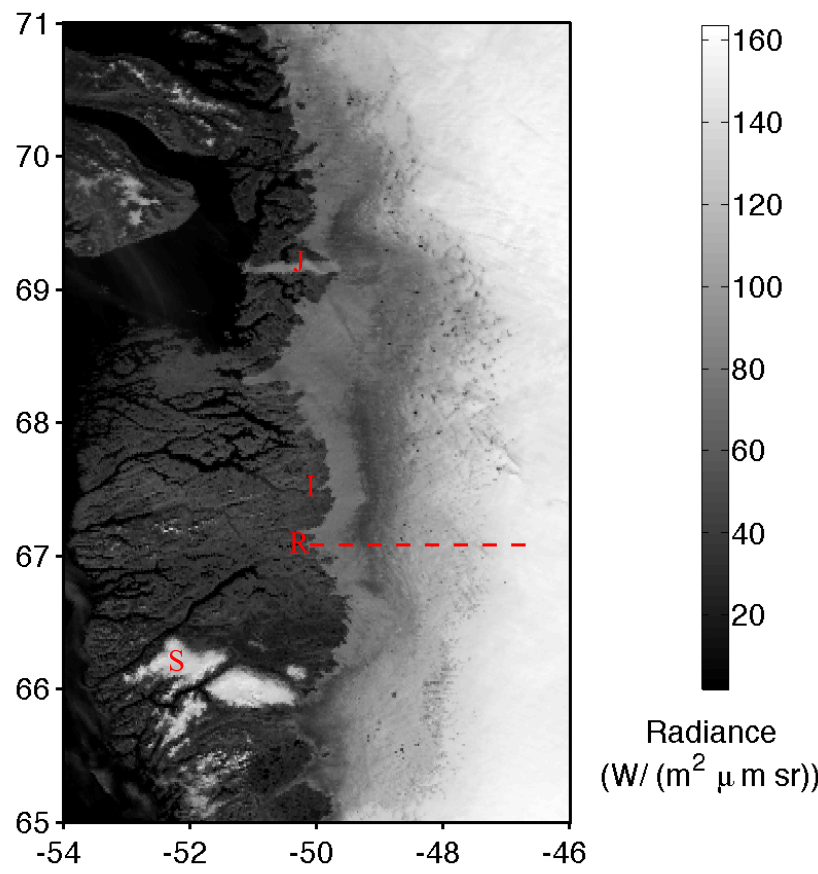

Fig. 1. MODIS image form 9 August 2007, band 2 (841-876 nm), showing the dark region in the ablation zone of West Greenland, adapted from Wientjes and Oerlemans (2010). S is Sukkertoppen Iskappe, $\mathrm{J}$ is Jakobshavn Isbrae, I is Inugpait Qûat, and R is Russell glacier, the starting point of the K-transect (dashed line). Latitudes and longitudes are shown along the axes.

spectral signature of the dark region, showing a pattern of lower reflectance in the visible light part of the spectrum typical for ice containing more dust, than the surrounding brighter ice. This dust can have two main sources; recent enhanced deposition of dust or accumulation through melting of outcropping ice that contains old dust layers (see Fig. 2). Because the dark region appears every year during the summer season, fixed at the same position at some distance from the margin, the dust is unlikely to be derived only from recent dry or wet deposition. In addition, satellite images reveal a wavy pattern in the dark ice, which is typical for the outcropping of tilted, stratified ice layers (Fig. 3). Therefore, the dust was probably initially deposited higher on the ice sheet, transported through the ice sheet towards the margin and released in the ablation zone (Wientjes and Oerlemans, 2010).

In case of an undisturbed stratigraphy, a horizontal surface ice profile in the ablation zone, perpendicular to the margin of the ice sheet, represents a time line; the closer to the margin, the older the ice (e.g. Reeh et al., 1987). Dust causing the dark region may thus originate from a period when more dust settled in the accumulation zone of the ice sheet. It might have been deposited during cold periods, due to dry and windy conditions (e.g. Fuhrer et al., 1999; Ruth et al., 2003). Alternatively, the dust could be volcanic material that was deposited on the ice (e.g. Clausen et al., 1997; Mortensen

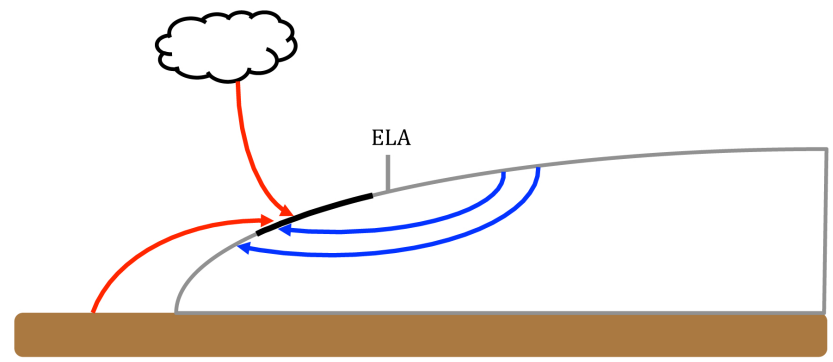

Fig. 2. Schematic overview of possible mechanisms for dust to reach the dark region. Both red lines indicate recent wind-blown material from the tundra and dry or wet deposition, whereas blue lines indicate the outcropping of the dust after settling higher on the ice sheet in the accumulation zone and travelling through the ice sheet. Dust following the blue trajectories has a certain age depending on the flow characteristics of the ice. ELA indicates the position of the Equilibrium Line Altitude, and the black line indicates the position of the dark region.
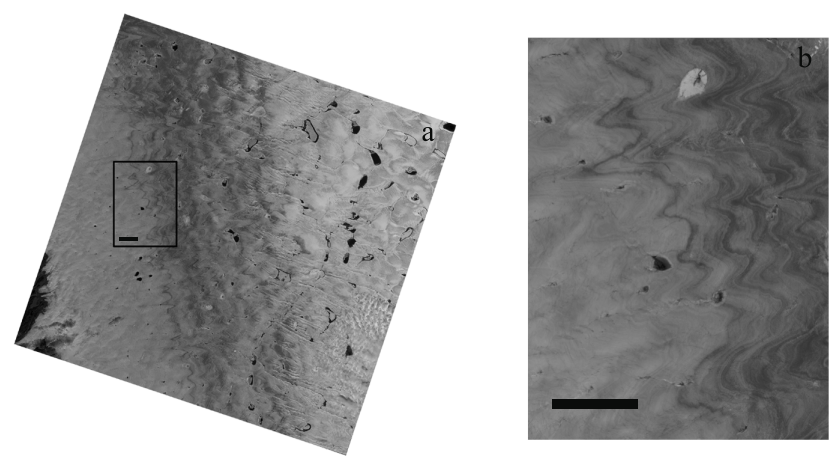

Fig. 3. (a) Aster image from 21 July 2002, adapted from Wientjes and Oerlemans (2010) (ㄷ) METI and NASA, 2002). The glacier in the left corner is Inugpait Qûat (see Fig. 1). (b) Inset of panel (a). The scale bar is approximately $3 \mathrm{~km}$. Panel (b) clearly shows a wavy pattern indicating outcropping stratified ice layers.

et al., 2005). Because the dark region is situated several kilometers to tens of kilometers from the margin, we assume that it will contain Holocene ice. This is in agreement with observations near Jakobshavn in the Pakitsoq area (Reeh et al., 2002; Petrenko et al., 2005), showing the transition between Holocene and Pleistocene ice at some hundreds of meters from the margin. In this area bands of dark ice, containing dust from colder glacial periods, were observed (Reeh et al., 2002; Petrenko et al., 2005). In north east Greenland, a brown band close to the margin was found to contain outcropping dust from intercontinental transport during the Pleistocene (Bøggild et al., 1996, 2010). Another dark zone in this ablation area is caused by local dust from outcropping ice, that originally was deposited high on the ice sheet (Bøggild et al., 2010).

Dust on the ice is often called cryoconite, as suggested by Nordenskjöld (1872). When this dust accumulates on the ice 
surface, it absorbs sunlight and often melts in the ice forming cryoconite holes. These holes deepen until the melt rate at the bottom of these holes equals the ablation rate at the ice surface (Gribbon, 1979). They are typically a few centimetres in diameter, and several centimetres to decimetres deep, water filled and with the cryoconite lying on the bottom (e.g. Gajda, 1958). Because the cryoconite holes contain sunlight and water, which in turn contains nutrients released from the dust minerals, they form an ideal habitat for microorganisms (Wharton et al., 1985). Cryoconite can significantly lower the albedo of the ice surface in the visible part of the spectrum (Takeuchi et al., 2001; Takeuchi, 2009; Bøggild et al., 2010). The locally formed organic matter of the cryoconite is one of the main factors for this albedo lowering. Takeuchi (2002) found that the amount of dark coloured organic substances, possibly the residue of bacterial decomposition of organic matter, determines the optical characteristics of the cryoconite. In addition, the aggregation of dark particles and organic debris by extracellular polymeric substances affects the light absorbency of the cryoconite (Hodson et al., 2010b). Uetake et al. (2010) found that a higher biovolume and differences in species composition account for the darker surface of Russell glacier compared to the Qaanaaq Glacier, both in West Greenland. They found higher amounts of inorganic matter as one of the reasons for the higher biovolume.

To elucidate the origin and characteristics of the surface dust in the dark region, cryoconite from the dark ice as well as from the brighter ice was collected and analysed. We sampled at various locations along the K-transect, a series of surface mass balance and weather station sites in western Greenland (Van de Wal et al., 2005). The sites are situated on a line perpendicular to the ice sheet margin around $67^{\circ} \mathrm{N}$, and cover both the dark region (S6, S7 and S8), and the bright ice closer to the margin (S4, SHR and S5), see Fig. 4. In this study, we analysed the shapes and the mineralogical composition of the collected grains and their elemental composition (Sect. 3), and the morphology and amount of microorganisms in the cryoconite (Sect. 4).

\section{Material and methods}

\subsection{Samples}

Cryoconite was collected from six sites along the K-transect (Table 1) on 2 and 3 September 2009. The number of samples was restricted by logistical constraints and surface conditions like snow or frozen holes. Table 1 shows the number of samples collected. At S7 and S8 we only managed to take small sized samples and samples from S8 did not yield enough material for the full suite of analyses. All the samples were kept under cool and completely dark circumstances, but where not kept frozen. To check whether preservation significantly affects our results, we analysed the cyanobacteria and algae from a small ice core that was taken at S7 during the

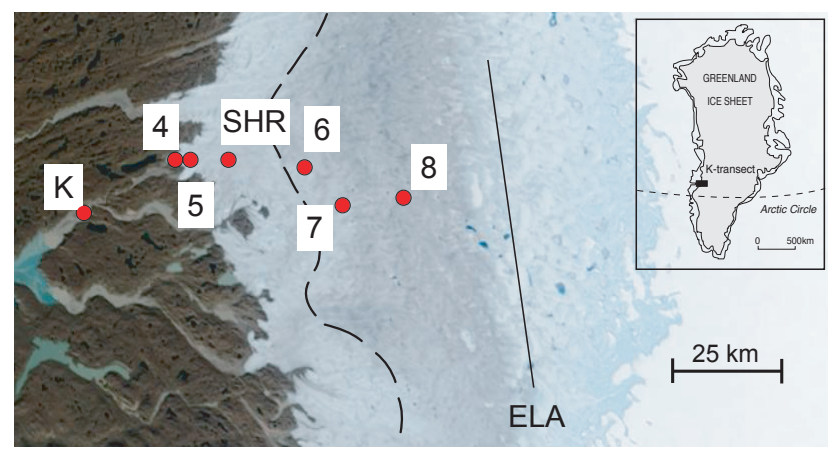

Fig. 4. The K-transect in West Greenland at $67^{\circ} \mathrm{N}$, adapted from Van de Wal et al. (2008). The background is a true colour composition of NASAModis/Terra from 26 August 2003. K is Kangerlussuaq and 4, 5, SHR, 6, 7 and 8 are surface mass balance sites. The dashed line indicates the western border of the dark region. ELA is the Equilibrium Line Altitude. Sites 4, 5 and SHR are in the brighter reference ice whereas Site 6, 7 and 8 are located in the dark region.

same field campaign and which has been kept in a frozen state since drilling. Optically, no significant differences were observed between the ice core organic matter and the samples described in this paper (see Fig. 5c and d). At some locations the cryoconite holes were deeper than expected; at S6 they were even about $50 \mathrm{~cm}$ deep. Although the holes were variable in depth among the locations, they had similar depths at individual sites, consistent with previous findings (e.g. Gribbon, 1979). Beside the cryoconite holes, part of the ice surface was covered with a uniform distributed dust layer. At S4, S5 and S6 large patches or streams of dust were present on the surface (Fig. 6). Part of these patches consist of clods of debris on the surface. Reasons why this accumulated dust did not melt in the ice could only be speculative. Probably the time of its presence on the ice surface was too short to form cryoconite holes and the locations on the foot of small hummocks prevent solar radiation to reach it. We collected dust from the holes as well as from these dust patches and streams. In between sampling, tools were rinsed with distilled water to prevent cross contamination among the samples. Analyses revealed no significant differences between dust from surface patches and streams, or dust from cryoconite holes.

\subsection{Geochemical analyses and microscopy}

The cryoconite was studied using both an optical microscope and a scanning electron microscope (SEM, XL30FEG, FEI). Together with SEM, Energy-Dispersive X-ray spectroscopy (EDX) was performed to qualitatively determine the bulk mineralogical composition of individual grains. For these measurements, material was mounted on a stub, dried and coated with carbon. The bulk mineralogical composition of the whole samples was qualitatively analysed by X-Ray Diffraction (XRD), using a powder diffractometer (AXS D8 Advance, Bruker) with Co-K $\alpha$ radiation. The samples were 
Table 1. Characteristics of sample locations (distances and heights are from Van de Wal et al., 2005, Table 1.)

\begin{tabular}{lcccccc}
\hline & Site 4 & Site 5 & SHR & Site 6 & Site 7 & Site 8 \\
\hline Latitude (N) & $67^{\circ} 05^{\prime} 45^{\prime \prime}$ & $67^{\circ} 05^{\prime} 59^{\prime \prime}$ & $67^{\circ} 05^{\prime} 44^{\prime \prime}$ & $67^{\circ} 04^{\prime} 39^{\prime \prime}$ & $66^{\circ} 59^{\prime} 31^{\prime \prime}$ & $67^{\circ} 00^{\prime} 16^{\prime \prime}$ \\
Longitude (W) & $50^{\circ} 11^{\prime} 08^{\prime \prime}$ & $50^{\circ} 07^{\prime} 12^{\prime \prime}$ & $49^{\circ} 56^{\prime} 07^{\prime \prime}$ & $49^{\circ} 23^{\prime} 17^{\prime \prime}$ & $49^{\circ} 08^{\prime} 19^{\prime \prime}$ & $48^{\circ} 52^{\prime} 02^{\prime \prime}$ \\
Height (ma.s.1.) & 390 & 490 & 710 & 1020 & 1110 & 1260 \\
Distance from margin (km) & 3 & 6 & 14 & 37 & 52 & 63 \\
Distance from equilibrium line (km) & 88 & 85 & 77 & 54 & 39 & 28 \\
Number of samples & 6 & 7 & 1 & 6 & 4 & - \\
\hline
\end{tabular}
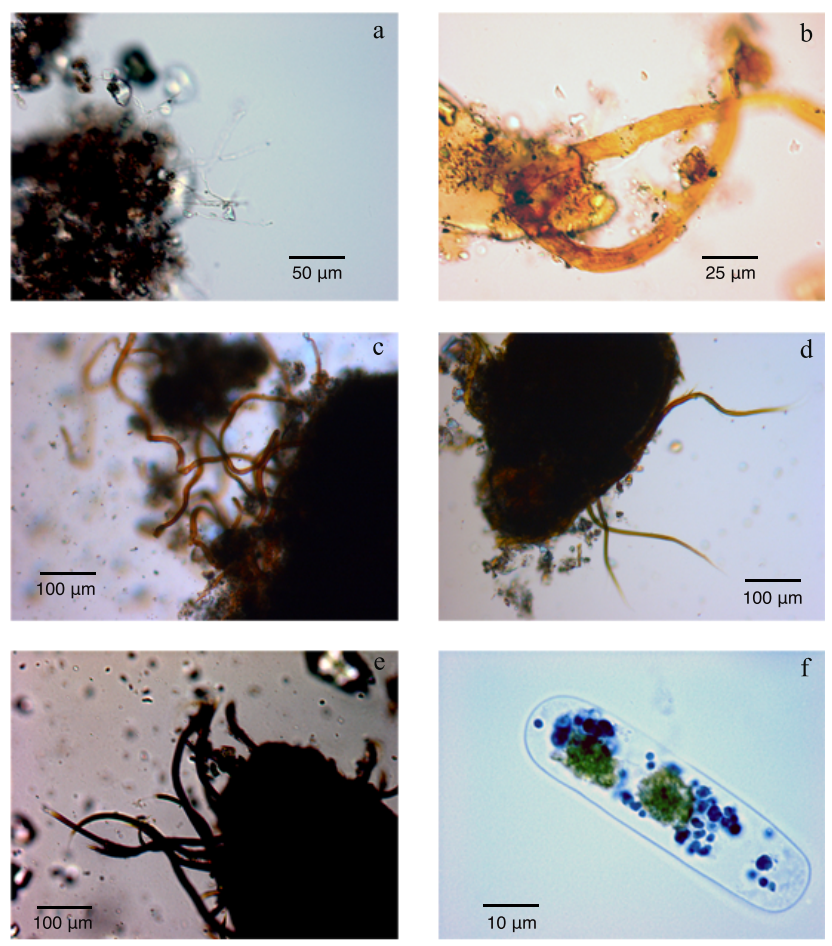

Fig. 5. Microorganisms in the cryoconite. (a) Small Cryoconite granule from S5. (b) Filamentous cyanobacteria from S7. (c) Cryoconite granule with brown cyanobacteria from S7. (d) Cryoconite with cyanobacteria from small ice core from S7. (e) Cryoconite granule with large black cyanobacteria from S6. (f) Green alga.

powdered in advance. The different minerals were identified based on their spectral characteristics.

Total Organic Carbon (TOC) and Nitrogen (N) concentrations were measured using an Elemental Analyser (NA 1500 NCS, Fisons). The material was decalcified prior to analyses by repeated rinsing with $1 \mathrm{M} \mathrm{HCl}(4 \mathrm{~h}, 12 \mathrm{~h})$ followed by washing with demineralized water. Concentrations measured on the decalcified residue were back corrected to their original values using the determined weight loss during decalcification. Because samples from S7 were too small for this procedure, they were decalcified by acidification with $25 \% \mathrm{HCl}$ in situ within silver sample cups as described in Nieuwenhuize et al. (1994). Only 3 out of 4 samples from
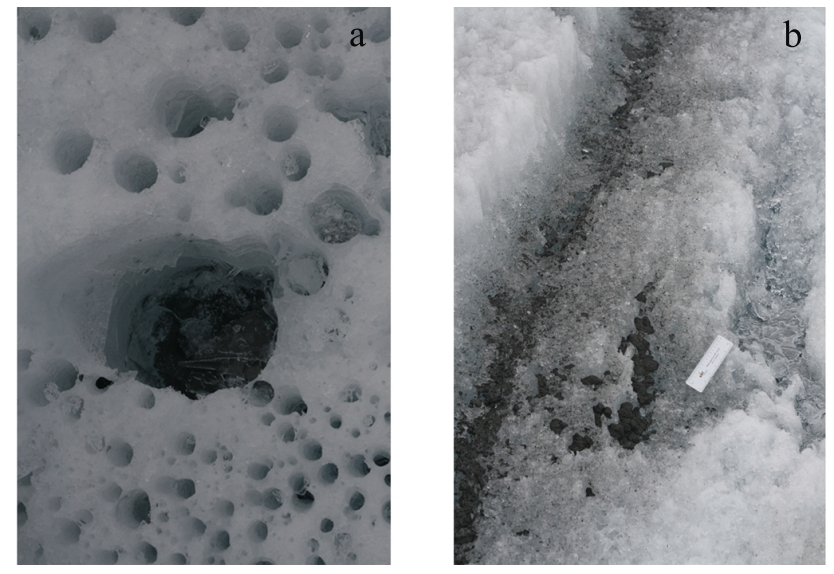

Fig. 6. Photos of the dust in the field. (a) Cryoconite holes at S5; the big hole has a diameter of $\sim 12 \mathrm{~cm}$. (b) Dust on the ice surface at $\mathrm{S} 5$; the white ruler to the right is $\sim 15 \mathrm{~cm}$ long. Part of this dust seems to form a stream along a small hummock.

S7 could be analysed. Based on duplicate analyses and including in-house standards the relative standard deviations for TOC and N were both better than $2 \%$ of the recorded weight percentage of TOC.

Total dust samples were dissolved in an acid mixture of $2.5 \mathrm{ml} \mathrm{mix}$ acid $\left(\mathrm{HClO}_{4}: \mathrm{HNO}_{3}=3: 2\right)$ and $2.5 \mathrm{ml} \mathrm{HF}$, and subsequently evaporated until gel was formed before being taken up again in $25 \mathrm{ml} 4.5 \% \mathrm{HNO}_{3}$ suprapur acid. Major elements were quantified using Inductively Coupled Plasma Atomic Emission Spectroscopy (ICP-AES, Spectro CIROS), minor and trace elements using Inductively Coupled Plasma Mass Spectroscopy (ICP-MS, X-Series II, Thermo Scientific). The elemental concentrations were calibrated against standard solutions. Duplicates were used to calculate relative standard deviations. The precision for all elements shown in this paper is better than $2.5 \%$ relatively, with the exception of Antimony, Arsenic and Mercury, which have a precision of $7.8 \%, 8.7 \%$ and $12.7 \%$, respectively.

The samples from S6 and S7 contain less inorganic material, because they were diluted by higher amounts of organic matter, as we will explain in Sect. 4. To overcome misinterpretation of the elemental composition, we corrected for the amount of organic matter in the samples. We have measured 

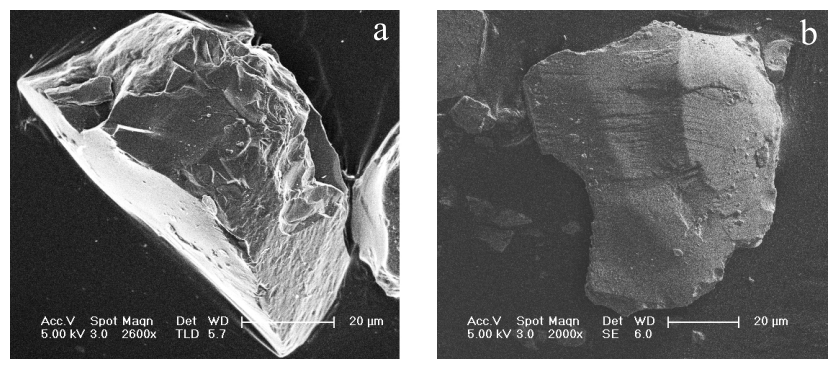

Fig. 7. (a) Sharp-edged and angular grain from S5. (b) Grain with abrasion features from $\mathrm{S} 8$.

the TOC and $\mathrm{N}$ concentrations of the samples and we assume that the total organic matter can be described by the mass of $\mathrm{CH}_{2} \mathrm{O}$ and $\mathrm{N}$. We multiplied the relative TOC concentrations for each site by 2.5 , based on the relative molecular weights ratio of $\mathrm{C}: \mathrm{CH}_{2} \mathrm{O}$ which is $12: 30$, and add the relative concentration of $\mathrm{N}$. The percentage of organic matter obtained in this way was used to correct all the element concentrations shown in this paper (Table 2 and 3 ).

\section{Grain shape and composition}

\subsection{Results}

Visual inspection using a light microscope and SEM revealed that the overall grain shapes at the various sites are similar. Most grains have rather angular shapes and are characterized by sharp edges (Fig. 7a). Some of the grains have abrasion features (see Fig. 7b). The cryoconite at S4 seems coarser than that at the other sites. Visual inspection with SEM revealed that material from this site contains larger grains than observed in the other samples.

The chemical composition of individual grains was assessed by EDX, whereas the bulk dust mineralogy was determined using XRD. Although the relative abundance of the various minerals might differ between the sites, all the samples analysed contained largely the same minerals. The EDX showed grains, each consisting of a single mineralogy, mainly quartz, feldspars and plagioclases and some micas. There are slight differences between dust from S4, consisting of quartz particles with some feldspars and plagioclases, and the other locations, where the abundance of plagioclase seems higher relative to that of quartz. A dominant contribution of these 3 minerals to the bulk dust composition is in line with the results of the XRD analyses. Figure 8 shows little variation between XRD curves for samples from each site. The samples mainly consist of quartz and albite with some anorthite. Minor amounts of phyllosilicate were also detected.

The samples from different locations contain similar concentrations of most elements (see Tables 2 and 3). When plotting element concentrations against each other, samples seem to cluster into two groups with S4 and S5 in one cluster, and S6 and S7 in the other cluster. For example, Fig. 9 shows this clustering when Tin (Sn) is plotted against Aluminium ( $\mathrm{Al}) . \mathrm{Al}$ is a major element associated with input of terrigenous, non-biogenic material, whereas $\mathrm{Sn}$ is a typical example of one of the minor elements that is more abundant in the dark region relative to the reference ice. SHR shows a different pattern, and seems to belong sometimes to one of the clusters and sometimes to form a group on its own. However, as there is only one single sample from this site, it is hard to assign a third cluster and draw firm conclusions For this reason data from SHR are not presented in Fig. 9. The clustering is observed for most of the elements. Only Phosphorus $(\mathrm{P})$ is quite different, with much higher concentrations at S4 than at the other sites. To observe the relative enrichment for each element, we divided the average concentration for samples from the dark region by the average concentration for samples from the reference ice. Figure 10 shows the results for part of the elements measured with either ICP-AES or ICP-MS. Values above 1 indicate that these elements are relatively enriched in the dark region with respect to the reference ice. Note that although some elements are much more abundant in the dark region than in the reference ice, the absolute concentrations still could be small. Although the element concentrations were corrected for dilution from organic matter content as explained in Sect. 2, we normalized the element concentrations in Fig. 10 to $\mathrm{Al}$, to overcome misinterpretation due to dilution by other unknown phases. Figure 11 shows the rare earth elements (REE) normalized to the averaged upper continental crust (Taylor and McLennan, 1995). The results for each location are averaged.

\subsection{Discussion}

The fragile, acute angles are typical for volcanic material, but have also been observed in glacial grains (Mahaney, 2002). However, large amounts of these angular-faceted, sharp-edged grains are found in both the dark region and the reference ice where precipitation rates are low and snow is eroded by wind (Van den Broeke et al., 2008). This excludes a single recent volcanic source. The other possibility for volcanic material to reach the ablation zone is by settling in the accumulation zone of the ice sheet during periods of volcanic activity, followed by transport through the ice, and subsequent accumulation through prolonged melting in the ablation zone. This outcropping volcanic material would, hence, be enriched in volcanic grains. However, grains transported together with the volcanic dust, but originating from different sources should also accumulate there. The overwhelming presence of acute edged particles, and the lack of rounded grains suggests that these grains became angular and sharpedged due to glacial transport itself, independent of their origin. Due to the grain-to-grain contact in the ice, the grains may suffer abrasion. The abrasion features on some of the 
Table 2. Averaged values ICP-AES in $\mathrm{g} \mathrm{kg}^{-1}$ for each site, corrected for organic material as explained in Sect. 2.

\begin{tabular}{lccccc}
\hline & Site 4 & Site 5 & SHR & Site 6 & Site 7 \\
\hline $\mathrm{Al}$ & $78.04 \pm 1.60$ & $80.36 \pm 2.44$ & $82.84 \pm 0.32$ & $86.20 \pm 0.66$ & $86.54 \pm 0.62$ \\
$\mathrm{Ba}$ & $0.610 \pm 0.025$ & $0.589 \pm 0.031$ & $0.556 \pm 0.004$ & $0.569 \pm 0.003$ & $0.580 \pm 0.008$ \\
$\mathrm{Ca}$ & $37.98 \pm 3.12$ & $38.26 \pm 0.74$ & $41.86 \pm 0.38$ & $35.99 \pm 0.68$ & $33.47 \pm 0.76$ \\
$\mathrm{Fe}$ & $47.82 \pm 8.87$ & $45.90 \pm 3.88$ & $56.56 \pm 0.47$ & $49.53 \pm 1.49$ & $45.53 \pm 2.76$ \\
$\mathrm{~K}$ & $14.13 \pm 0.34$ & $13.92 \pm 0.55$ & $14.82 \pm 0.12$ & $17.07 \pm 0.13$ & $17.07 \pm 0.37$ \\
$\mathrm{Mg}$ & $15.53 \pm 2.88$ & $16.16 \pm 1.28$ & $21.00 \pm 0.13$ & $18.80 \pm 0.46$ & $16.99 \pm 0.99$ \\
$\mathrm{Mn}$ & $0.81 \pm 0.14$ & $0.78 \pm 0.05$ & $0.92 \pm 0.01$ & $0.72 \pm 0.02$ & $0.65 \pm 0.03$ \\
$\mathrm{Na}$ & $27.84 \pm 1.07$ & $28.71 \pm 1.39$ & $27.45 \pm 0.14$ & $26.93 \pm 0.22$ & $27.10 \pm 0.72$ \\
$\mathrm{P}$ & $0.60 \pm 0.11$ & $0.29 \pm 0.06$ & $0.30 \pm 0.01$ & $0.42 \pm 0.02$ & $0.38 \pm 0.06$ \\
$\mathrm{Sr}$ & $0.353 \pm 0.013$ & $0.365 \pm 0.018$ & $0.345 \pm 0.003$ & $0.336 \pm 0.003$ & $0.340 \pm 0.009$ \\
$\mathrm{Ti}$ & $4.43 \pm 0.89$ & $4.02 \pm 0.40$ & $5.01 \pm 0.03$ & $4.63 \pm 0.17$ & $4.27 \pm 0.31$ \\
\hline
\end{tabular}

Table 3. Averaged values ICP-MS in ppm for each site, corrected for organic material as explained in Sect. 2.

\begin{tabular}{|c|c|c|c|c|c|}
\hline & Site 4 & Site 5 & SHR & Site 6 & Site 7 \\
\hline $\mathrm{Li}$ & $9.60 \pm 0.75$ & $9.63 \pm 0.35$ & $12.43 \pm 0.08$ & $16.79 \pm 0.36$ & $17.91 \pm 1.15$ \\
\hline $\mathrm{Be}$ & $0.98 \pm 0.04$ & $1.00 \pm 0.03$ & $1.12 \pm 0.04$ & $1.22 \pm 0.02$ & $1.31 \pm 0.02$ \\
\hline $\mathrm{V}$ & $109.83 \pm 19.30$ & $107.16 \pm 9.94$ & $132.39 \pm 3.30$ & $120.16 \pm 3.62$ & $118.59 \pm 7.51$ \\
\hline $\mathrm{Cr}$ & $100.38 \pm 20.52$ & $112.28 \pm 10.66$ & $156.20 \pm 4.30$ & $144.79 \pm 6.62$ & $129.47 \pm 5.48$ \\
\hline Co & $15.06 \pm 2.69$ & $14.80 \pm 1.22$ & $18.11 \pm 0.54$ & $15.46 \pm 0.43$ & $14.39 \pm 0.81$ \\
\hline $\mathrm{Ni}$ & $33.02 \pm 6.90$ & $35.78 \pm 2.89$ & $48.00 \pm 1.20$ & $46.37 \pm 2.34$ & $57.48 \pm 12.55$ \\
\hline $\mathrm{Zn}$ & $58.11 \pm 10.91$ & $53.80 \pm 4.49$ & $69.13 \pm 1.46$ & $68.94 \pm 2.90$ & $81.54 \pm 10.92$ \\
\hline $\mathrm{Ga}$ & $12.00 \pm 0.30$ & $11.67 \pm 0.36$ & $11.60 \pm 0.44$ & $11.98 \pm 0.21$ & $12.46 \pm 0.09$ \\
\hline As & $4.50 \pm 0.60$ & $4.93 \pm 0.40$ & $5.76 \pm 0.94$ & $7.08 \pm 0.62$ & $13.77 \pm 5.05$ \\
\hline $\mathrm{Rb}$ & $29.58 \pm 1.15$ & $27.80 \pm 1.12$ & $33.40 \pm 0.69$ & $47.47 \pm 0.99$ & $49.75 \pm 2.26$ \\
\hline $\mathrm{Y}$ & $18.57 \pm 3.33$ & $16.15 \pm 1.26$ & $18.78 \pm 0.40$ & $16.12 \pm 0.47$ & $15.51 \pm 0.85$ \\
\hline $\mathrm{Nb}$ & $7.51 \pm 1.39$ & $6.48 \pm 0.62$ & $8.41 \pm 0.24$ & $9.58 \pm 0.26$ & $9.25 \pm 0.75$ \\
\hline $\mathrm{Cd}$ & $0.166 \pm 0.027$ & $0.166 \pm 0.012$ & $0.228 \pm 0.001$ & $0.269 \pm 0.011$ & $0.421 \pm 0.086$ \\
\hline $\mathrm{Sn}$ & $1.10 \pm 0.21$ & $1.12 \pm 0.09$ & $1.64 \pm 0.01$ & $2.35 \pm 0.09$ & $2.83 \pm 0.32$ \\
\hline $\mathrm{Sb}$ & $0.09 \pm 0.05$ & $0.08 \pm 0.05$ & $0.19 \pm 0.01$ & $0.46 \pm 0.05$ & $0.61 \pm 0.03$ \\
\hline Cs & $0.200 \pm 0.049$ & $0.257 \pm 0.031$ & $0.822 \pm 0.004$ & $2.360 \pm 0.125$ & $2.589 \pm 0.256$ \\
\hline $\mathrm{La}$ & $34.19 \pm 6.57$ & $31.02 \pm 2.17$ & $34.16 \pm 0.44$ & $29.09 \pm 1.01$ & $29.34 \pm 2.14$ \\
\hline $\mathrm{Ce}$ & $71.49 \pm 14.57$ & $64.76 \pm 4.82$ & $72.19 \pm 0.96$ & $61.97 \pm 1.91$ & $59.70 \pm 4.69$ \\
\hline $\operatorname{Pr}$ & $8.39 \pm 1.68$ & $7.49 \pm 0.58$ & $8.48 \pm 0.06$ & $7.15 \pm 0.23$ & $6.88 \pm 0.49$ \\
\hline $\mathrm{Nd}$ & $31.34 \pm 6.30$ & $27.84 \pm 2.10$ & $31.74 \pm 0.14$ & $26.81 \pm 0.81$ & $26.09 \pm 1.81$ \\
\hline $\mathrm{Sm}$ & $5.47 \pm 1.09$ & $4.76 \pm 0.35$ & $5.46 \pm 0.03$ & $4.71 \pm 0.12$ & $4.50 \pm 0.28$ \\
\hline $\mathrm{Eu}$ & $1.44 \pm 0.21$ & $1.29 \pm 0.06$ & $1.42 \pm 0.01$ & $1.23 \pm 0.02$ & $1.17 \pm 0.07$ \\
\hline $\mathrm{Gd}$ & $5.25 \pm 1.05$ & $4.50 \pm 0.35$ & $5.20 \pm 0.03$ & $4.46 \pm 0.10$ & $4.31 \pm 0.27$ \\
\hline $\mathrm{Tb}$ & $0.69 \pm 0.14$ & $0.59 \pm 0.04$ & $0.68 \pm 0.02$ & $0.59 \pm 0.02$ & $0.56 \pm 0.04$ \\
\hline Dy & $3.76 \pm 0.72$ & $3.26 \pm 0.25$ & $3.84 \pm 0.13$ & $3.34 \pm 0.08$ & $3.16 \pm 0.20$ \\
\hline Нo & $0.75 \pm 0.15$ & $0.65 \pm 0.05$ & $0.76 \pm 0.02$ & $0.66 \pm 0.01$ & $0.63 \pm 0.04$ \\
\hline $\mathrm{Er}$ & $2.09 \pm 0.41$ & $1.85 \pm 0.11$ & $2.15 \pm 0.06$ & $1.93 \pm 0.05$ & $1.82 \pm 0.11$ \\
\hline $\mathrm{Tm}$ & $0.30 \pm 0.06$ & $0.26 \pm 0.02$ & $0.32 \pm 0.01$ & $0.28 \pm 0.01$ & $0.26 \pm 0.02$ \\
\hline $\mathrm{Yb}$ & $1.98 \pm 0.40$ & $1.76 \pm 0.12$ & $2.11 \pm 0.07$ & $1.85 \pm 0.05$ & $1.74 \pm 0.10$ \\
\hline $\mathrm{Lu}$ & $0.30 \pm 0.06$ & $0.27 \pm 0.02$ & $0.32 \pm 0.01$ & $0.28 \pm 0.01$ & $0.27 \pm 0.02$ \\
\hline $\mathrm{Hg}$ & $0.025 \pm 0.005$ & $0.024 \pm 0.007$ & $0.044 \pm 0.017$ & $0.068 \pm 0.017$ & $0.076 \pm 0.031$ \\
\hline $\mathrm{Tl}$ & $0.18 \pm 0.02$ & $0.17 \pm 0.01$ & $0.22 \pm 0.01$ & $0.34 \pm 0.01$ & $0.36 \pm 0.03$ \\
\hline $\mathrm{Pb}$ & $11.07 \pm 0.77$ & $11.88 \pm 0.69$ & $15.23 \pm 0.88$ & $25.9 \pm 0.85$ & $29.32 \pm 0.81$ \\
\hline $\mathrm{U}$ & $0.74 \pm 0.18$ & $0.71 \pm 0.05$ & $0.92 \pm 0.03$ & $1.12 \pm 0.04$ & $1.15 \pm 0.10$ \\
\hline
\end{tabular}



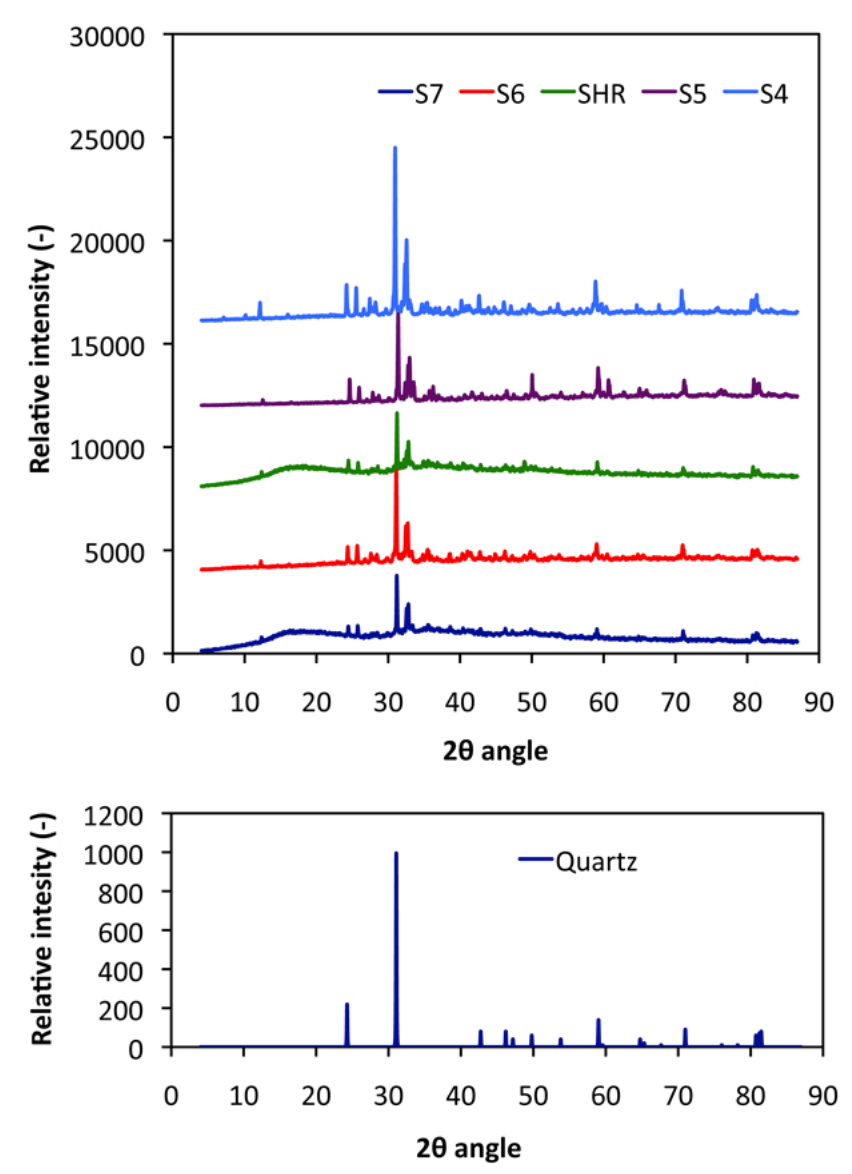

Fig. 8. XRD curves, showing little differences between cryoconite from the different Sites. For comparison, the XRD curve of pure quartz is plotted in the lower panel. The higher levels for small angles for S7 and SHR are due to a smaller sample holder.

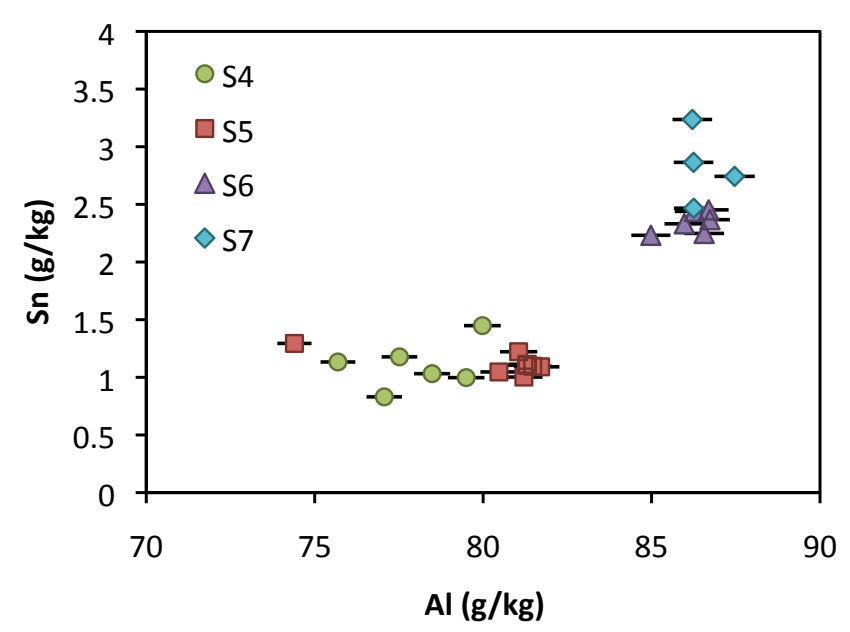

Fig. 9. Tin ( $\mathrm{Sn}$ ) versus Aluminium (Al) for the samples from four different locations.
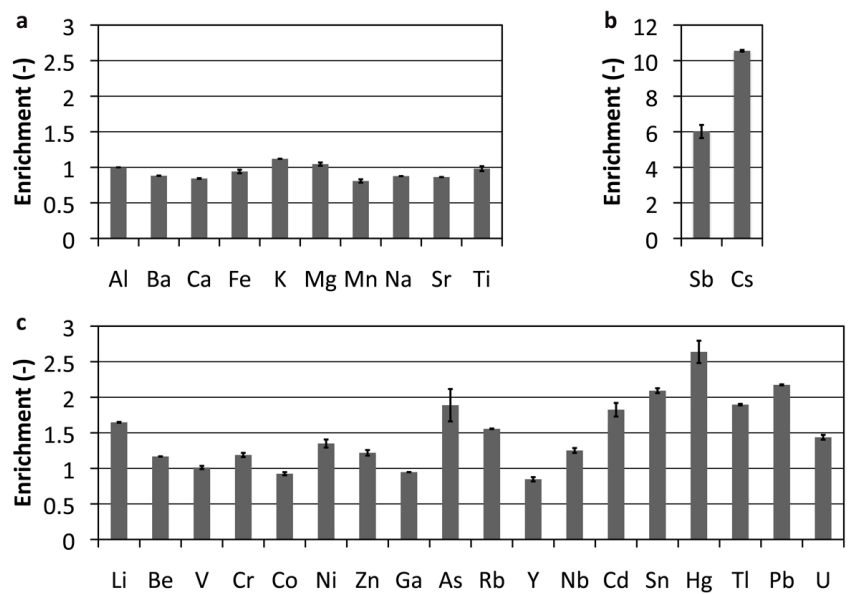

Fig. 10. Enrichment of elements for the dark region, calculated as the average concentration for samples from the dark region devided by $\mathrm{Al}$ devided by the average concentration for samples from the reference ice devided by Al. Panel (a) shows elements measured with ICP-AES and panel (b) and (c) show elements measured with ICP-MS. Error bars represent one standard deviation. Note the different scale in panel (b).

grains confirm that the grains indeed have been transported through the ice. In theory, the material could also be entrained from the underlying bedrock. This seems unlikely, however, as the higher sites (S7 and S8) are located close to the equilibrium line, and particle trajectories through the ice towards these sites do not get close to the bottom. We therefore conclude that at least part of the dust originates from higher parts of the ice sheet, travelled through the ice and accumulates in the ablation zone at present due to the melting of outcropping ice.

The mineralogical composition of our samples is similar to cryoconite from the same area, investigated by Langford et al. (2010), although small differences were recorded. This can be due to the fact that their samples were taken closer to margin, where basally-entrained material may also be present (Hodson et al., 2010a). Langford et al. (2010) found contributions of apatite in their samples. Although we did not detect any apatite, some small contributions of these minerals may account for the high amounts of P at S4 (which is located closest to their sampling sites). At S4 we found also coarser grains and slightly higher amounts of quartz. As this site is located close to the margin, a possible higher influx of wind-blown material from the nearby tundra or some material entrained from the bedrock might have been added to the other grains at this site. However, Yde et al. (2010) investigated basally derived debris at the margin of Russell glacier, near our sampling sites, and found it mainly consisting of plagioclases and amphibole. Although the mineral composition of their samples seems comparable with our samples for other mineral groups, we did not detect high amounts of amphibole in our samples. This might by due to the slightly 
different locations or because only small or no amounts of bedrock material are added at S4.

Maggi (1997) investigated changes in the mineralogy of atmospheric dust in the GRIP ice core spanning the time interval between the Eemian and the last glacial maximum, and noted two distinct assemblages with different characteristics during cold and warm episodes. One consists mainly of quartz, illite, chlorite, micas and feldspars, related to cold mid-high-latitude source areas; and the other consists mainly of kaolinite and $\mathrm{Fe}$ (hydr)oxides, related to warm and humid low-latitude source areas. As our samples do not contain kaolinite and as we did not detect any Fe (hydr)oxidescoated grains using EDX, our samples are most similar to the first assemblage of Maggi (1997), excluding low-latitude areas as source for the dust. Svensson et al. (2000) investigated twelve glacial dust samples from the GRIP ice core, and indicated eastern Asia being the main source for these samples originating from the Younger Dryas, the Bølling, the Last Glacial Maximum and cold and mild glacial periods back to $44 \mathrm{kyr}$ BP. They found higher kaolinite/chlorite ratios and lower feldspar content in the dust from cold glacial periods relative to warmer periods. This is in contrast with the findings by Maggi (1997). However, as the mineralogical composition of our samples differs from the mineralogical composition of all samples from Svensson et al. (2000), eastern Asia does not qualify as the main source for the dust in the dark region. This is probably due to the fact that our samples originate from a period within the Holocene, when circumstances were less dry and windy than during glacial conditions. Besides, the high relative abundance of feldspars and plagioclases relative to the quartz in our samples is likely due to a lesser degree of chemical weathering, or a more felsic nature of the source rock for the dust. For this reason, sources that have undergone significant weathering, such as old deserts, can be excluded as the origin of the cryoconite, because the dust from such sources consists mainly of quartz.

The clustering between samples from S4 and S5 and from S6 and S7 suggests compositional differences between samples from the dark region and from the reference ice, as S6 and S7 are both located in the dark region, whereas S4 and S5 are located in the brighter ice close to the margin. Especially Caesium (Cs) is much more abundant in the dark region, but heavy metals such as Lead (Pb), Antimony ( $\mathrm{Sb}$ ) and Mercury ( $\mathrm{Hg}$ ) also have larger concentrations in the dark region (Fig. 7). These are all elements associated with anthropogenic pollution (Nriagu and Pacyna, 1988). It is therefore tempting to argue that the dark region is caused by outcropping modern dust. However, this is not the case, as the distance from S6 and S7 to the equilibrium line is too large for dust transport through the ice sheet since the industrial revolution. Consequently, the enrichment of these elements in the dark region seemed to be caused by direct deposition at the surface. This net deposition is smaller at S4 and S5, possibly because most snow is blown away immediately at these sites (Van den Broeke et al., 2008), and melt rates are higher with

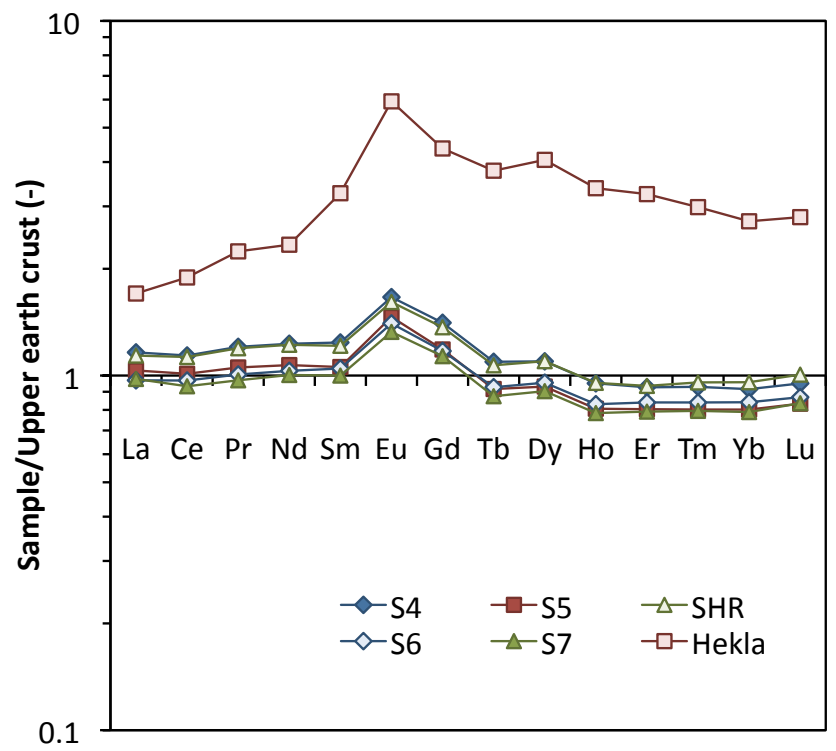

Fig. 11. Rare earth element pattern of the averaged concentration for each location normalized to the upper continental crust. Tephra from the 2000 Hekla eruption is shown for comparison.

respect to the dark region due to the lower elevations (see Table 1). In addition, these elements might accumulate due to uptake by microorganisms, which are much more abundant in the dark region (Sect. 4). We observed a good correlation between TOC and the concentrations of these metals, which suggest that absorption to organic metal bonds might also influence their concentrations.

The rare earth element (REE) values are close to 1, when they were normalized to the averaged upper continental crust (Fig. 11). This means that the average composition of the collected surface dust resembles the average composition of the upper earth crust, as well as the average composition of volcanic material, as most of the upper earth crust originates from volcanic material. In addition, the REE patterns for the different sampling sites resemble each other closely. REE patterns of dust samples often show more variation, for example glacial dust from ice cores in Antarctica (Basile et al., 1997). The outcropping dust at the 5 sampling locations originate from 5 different periods, because a horizontal transect can be seen as a time line, as explained in the introduction. If dust from a single event, like a large volcanic eruption, settled in the accumulation zone of the Greenland ice sheet and is now outcropping at one of these sites, it should alter the REE pattern for that specific site. As this is not the case, we exclude a single volcanic eruption as a possible source for the dust. Icelandic volcanoes are close enough and erupt often enough to possibly contribute to the outcropping material at all 5 sites. However, Icelandic volcanoes show a different REE pattern and can therefore be excluded as possible origin of this dust. For comparison, the REE pattern from tephra of the February 2000 eruption of Hekla (Moune et al., 2006) 
is added in Fig. 8. For these two reasons, a volcanic cause for the dark region seems unlikely. As the REE patterns for the different sites reveal a source with a chemical composition similar to the upper continental crust, the material does not seem to contain micrometeorites, which have been found on the Greenland ice sheet (Maurette et al., 1987). This is confirmed by our microscopic analyses.

Summarizing, part of the dust consists of outcropping material that initially settled higher on the ice sheet during dustier periods, although common source areas for glacial dust, like Asian desserts, can be excluded as provenance for this dust. Also volcanic eruptions or micrometeorites were unlikely to cause the dark region. As both the mineralogical composition (XRD-curves, Fig. 8) and the REE patterns do not show large variations, we conclude that the dust from the 5 different sites has mainly the same origin; although dust from the dark region seems enriched with elements from the current atmosphere due to anthropogenic pollution or by binding to organic matter. As the outcropping dust at these 5 different sites originates from 5 different periods, the same origin for the dust during these different periods indicates a local source, probably the nearby tundra. Material from S4 seems partly derived by wind blown material from the tundra or by basally entrained material, but the composition is mainly the same as the material from the other sites, strengthening the argument of local dust for all sites. The only consistent explanation for all measurements is a local origin for the dust in the dark region.

\section{Microorganisms}

\subsection{Results}

Visual inspection with a light microscope using normal light revealed that the cryoconite also contains microorganisms (Fig. 5). No organisms could be detected at S4 and only small granules containing organic matter were visible in samples from S5 (Fig. 5a). However, samples from all other sites contain long yellow-brownish filamentous strings that represent cyanobacteria (Takeuchi, personal communication). These bacteria are present, not only as loose strings in the samples (Fig. 5b), but are also aggregated in granules, together with mineral particles and organic matter. At S6 these cryoconite granules appeared very dark-coloured using the transmitted light microscope, and are therefore large and thick-walled (Fig. 5e), whereas the cryoconite granules from SHR, S7 and S8 were covered with yellow or brown strings of cyanobacteria (Fig. $5 \mathrm{c}$ and d). In addition, we noted abundant occurrence of green algae at the higher altitude sites (Fig. 5f).

The TOC measurements on dry cryoconite confirmed our microscope observations that organic matter was abundantly present at sites from the dark region (Table 4). All the samples from S4 have a TOC content $<0.2$ weight percent (\%) and all the samples from S5 have a TOC content $<0.8 \%$ (the

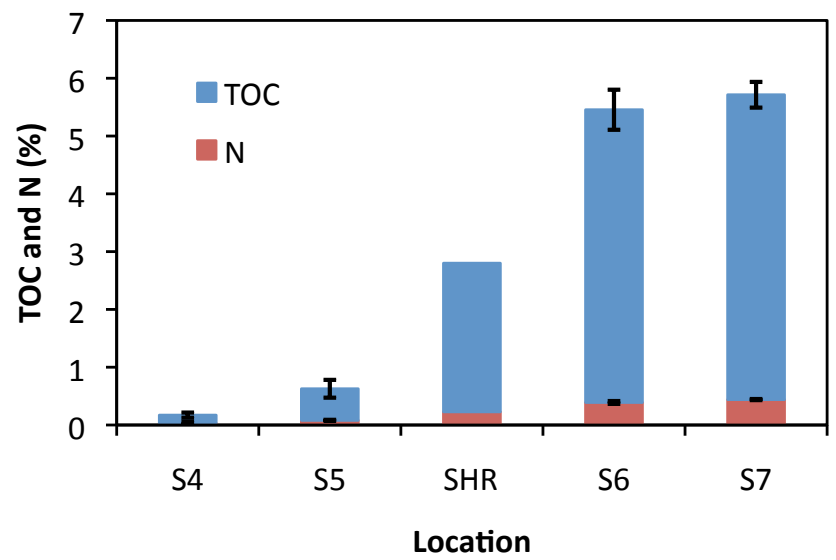

Fig. 12. The averaged concentrations of total organic carbon (TOC) and nitrogen $(\mathrm{N})$ for each location; error bars represent one standard deviation.

lowest value is $0.36 \%$ ). In contrast, the samples from S6 and S7 contain between $4.5 \%$ and $5.5 \%$ TOC. From SHR we have only one measurement, indicating a TOC content of $2.6 \%$. Figure 12 shows the averaged percentage of total organic carbon (TOC) and nitrogen (N) for the different sites. The ratio $\mathrm{C} / \mathrm{N}$ ranges between 11.3 and 13.5 dry weight (13.18-15.75 molar) for all the samples from SHR, S6 and S7. Because the TOC and $\mathrm{N}$ values are low for the samples from $\mathrm{S} 4$ and $\mathrm{S} 5$, their $\mathrm{C} / \mathrm{N}$ ratio is determined by the slope of the trend line through the plotted values of $\mathrm{C}$ against $\mathrm{N}$. This is done to overcome misinterpretation as result of small nitrogen leakage during the measurements. The $\mathrm{C} / \mathrm{N}$ ratio is around 12.2 dry weight (14.2 molar) for the samples from these sites.

\subsection{Discussion}

The microscopic observations provide a good qualitative indication of microorganisms that influenced the light absorbency of the material. Although the cryoconite might contain small microorganisms (Yallop and Anesio, 2010), large dark organic granules are likely to be more important for albedo lowering than small microbes. These granules seem larger and more abundant in the dark region than in the brighter reference ice. Concentrations of TOC and N agree well with these findings and increase with elevation. This is also in agreement with Stibal et al. (2010), who measured the concentration of organic carbon on almost the same transect as where we collected our samples. TOC values in the dark region (S6 and S7) are rather high in comparison with other Arctic sites (Tables 4 and 5). Reported values ranges between $2.03 \%$ and $4.37 \%$. Bøggild et al. (2010) found cryoconite from northeast Greenland containing $5 \%$ organic matter (OM), based on loss on ignition (LOI), and Takeuchi (2009) measured $2.9 \%$ to $8.8 \%$ organic matter in the surface dust from ice from the Gulkana Glacier, Alaska Range, USA. 
Table 4. Averaged TOC, $\mathrm{N}$ and $\mathrm{C} / \mathrm{N}$ mass ratios for the different sites.

\begin{tabular}{llll}
\hline Location & $\mathrm{C} / \mathrm{N}(-)$ & TOC $(\%)$ & $\mathrm{N}(\%)$ \\
\hline Site 4 & 12.2 & $0.14 \pm 0.04$ & $0.03 \pm 0.02$ \\
Site 5 & 12.2 & $0.55 \pm 0.15$ & $0.08 \pm 0.01$ \\
SHR & 11.3 & 2.57 & 0.23 \\
Site 6 & 13.0 & $5.06 \pm 0.35$ & $0.39 \pm 0.02$ \\
Site 7 & 12.0 & $5.27 \pm 0.22$ & $0.44 \pm 0.01$ \\
\hline
\end{tabular}

Because organic matter consists not only of TOC, but also of $\mathrm{H}$ and $\mathrm{O}$, organic matter concentrations must be higher than TOC concentrations (see Table 5). Hence the value of $5 \%$ TOC for the cryoconite from the dark region indicates that the organic matter content of these samples is higher than for cryoconite from north east Greenland and probably higher than the values found by Takeuchi (2009). Hodson et al. (2010a) investigated basally derived debris and cryoconite from blue ice in the same area, but closer to the ice margin than our sampling locations, and found organic matter contents based on LOI of $1.9 \%$ and $7.1 \%$, respectively.

The $\mathrm{C} / \mathrm{N}$ values of our samples are higher than the $\mathrm{C} / \mathrm{N}$ molar rations of 8-9 observed by Stibal et al. (2010), but seem to compare reasonably well with other values found for cryoconite on Artic glaciers (Table 5). Takeuchi (2002) found $\mathrm{C} / \mathrm{N}$ mass ratios between 9 and 14 (mostly around 11) for different cryoconites of nine glaciers from the Himalaya, Tibet, and the Arctic. In addition, Hodson et al. (2010b) found a $\mathrm{C} / \mathrm{N}$ mass ratio of $13 \pm 1$ for cryoconite from Longyearbreen, a valley glacier in Svalbard.

It is not obvious why the TOC and $\mathrm{N}$ increase with altitude. However, we assume that most of the cryoconite is formed in situ. This is confirmed by Hodson et al. (2010a) who found significant biological activity (based on respiration and photosynthesis rates) within the cryoconite from blue ice where organic matter content was high, but almost no activity within the debris from the marginal zone where organic matter content was low. In addition, the measurements done by Stibal et al. (2010) on cryoconite from almost the same transect, reveal autochthonous organic matter content together with some allochthonous plant material. They found the highest contents of microbial produced matter compared to allochthonous organic matter at $10 \mathrm{~km}$ distance from the margin and onwards, confirming our assumption of in situ formation of the cryoconite. Stibal et al. (2010) speculate that water drainage from and wind transport towards the ice sheet affect the TOC content of the cryoconite, whereas microbial abundance seems controlled by microbial productivity and water drainage.

As we explained in the introduction, we assume that the dark region is caused by higher amounts of dust (based upon findings by Wientjes and Oerlemans, 2010). Therefore, the larger TOC content relative to the cryoconite at high altitudes seems either caused by higher biological productivity or by higher outwash of organic matter at the lower altitudes.

Possibly higher biological productivity at the higher altitudes can not be explained by a higher nutrient supply due to more mineral dust, as relative amounts of useful elements are similar in the dark region with respect to the reference ice. Phosphorus, which is an essential nutrient for the cyanobacteria, is even higher at S4 compared to the other sites. Also the $\mathrm{pH}$ of the ice and water, that might affect the biological activity, is similar at all sites, with values ranging from 4.6 to 5.2 , both for water in the cryoconite holes as well as in the surrounding supraglacial streams. These values are slightly lower than values for surface ice from the Gulkana Glacier in Alaska, which are between 4.9 and 5.7 (Takeuchi, 2001). Stibal et al. (2006) suggest that microorganisms prefer fine sediment in the cryoconite. As the cryoconite at S4 contains coarser material than the other sites, this might also contribute to the absence of cyanobacteria at S4. At the higher elevations, the ice is covered by snow for a greater proportion of the year, which is more likely to reduce algal growth. However, global radiation strongly increases with altitude on the Greenland ice sheet, because of decreasing cloudiness and a more transparent atmosphere (Konzelmann et al., 1994). This effect might be an important factor for the biological activity. Another explanation for the increased TOC with elevation, although speculative, is that part of the organic material was blown on the accumulation zone of the ice sheet in conjunction with the high amounts of dust, in a period when much more dust from local sources was transported to the ice sheet. This organic matter consequently travelled through the ice together with the dust, and algae start multiplying once they are at the surface again.

Takeuchi (2001) found that the abundance of algae increase with altitude at Gulkana Glacier, Alaska, caused by the outwash of the algae at lower sites where more melt occurred, as the microorganisms on this glacier mainly consist of unicellular green algae that do not form cryoconite granules. If aggregations form between cyanobacteria, organic matter and mineral particles, these granules are more resistant against flushing by melt water (Takeuchi, 2001). In our case these aggregations formed, and it is very unlikely that they completely washed out at S4, where we observed no microorganisms but considerable amounts of dust. Green algae are only present in abundance at the higher elevations, suggesting that they could have been flushed away from the ice sheet at the lower sites due to the higher melt rates and runoff.

Despite the fact that it is uncertain what causes the occurrence of cryoconite granules at higher altitudes, it is well known that they have a high light absorbency (e.g. Takeuchi et al., 2001). As these granules are abundant in the dark region, we can conclude that relative higher amounts of dark organic matter is likely to contribute to the surface darkening process. 
Table 5. TOC, N, C/N mass ratios and OM for cryoconite from other Arctic regions.

\begin{tabular}{llllll}
\hline Location & $\mathrm{C} / \mathrm{N}(-)$ & TOC $(\%)$ & $\mathrm{N}(\%)$ & OM $(\%)$ & Reference \\
\hline Transect along $67^{\circ} \mathrm{N}$ & $8-9$ (molar) & $\begin{array}{l}0->6 \\
\text { (increasing } \\
\text { with distance) }\end{array}$ & $\begin{array}{l}\text { (increasing } \\
\text { with distance) }\end{array}$ & & Stibal et al. (2010) \\
Austre Broggerbreen & 10.8 (mass) & 4.37 & 0.4 & 9.7 & Takeuchi (2002) \\
Penny Ice Cap & 10.7 (mass) & 2.22 & 0.21 & 11.6 & Takeuchi (2002) \\
Devon Ice Cap & 9.0 (mass) & 2.06 & 0.23 & 11.4 & Takeuchi (2002) \\
Longyearbreen & 12.98 (mass) & 2.03 & 0.16 & 8.0 & Hodson et al. (2010b) \\
Gulkana glacier & & & & $2.9-8.8$ & Takeuchi (2009) \\
North east Greenland & & & 5 & Bøggild et al. (2010) \\
Kangerlussuaq blue ice & & & & 7.1 & Hodson et al. (2010a) \\
Kangerlussuaq marginal ice & & & 1.9 & Hodson et al. (2010a) \\
\hline
\end{tabular}

\section{Conclusions}

In order to find out more about the characteristics of cryoconite from the dark region, surface material was collected and analysed from locations inside the dark region, and from locations of brighter ice closer to the ice margin. Using both transmitted light microscopy and electron microscopy, we observed triangular-faceted, sharp-edged grains, which are either volcanic or glacial grains. The high amounts of these grains can not originate from recent deposition only, especially at the lower sites were precipitation rates are low and wind erosion large. Therefore both type of grains indicate glacial transport. This implies that at least part of the dust is derived from the outcropping ice, in both the dark region and the reference area. Geochemical analyses revealed that the mineralogical and elemental composition of the material is mostly the same for both areas. Enrichment of some elements in the dark region is explained by higher supply from recent anthropogenic material by precipitation or binding of these elements to the higher amounts of organic matter.

The REE patterns for the different sites resemble the averaged upper continental crust. Based on these patterns and on the SEM images, the material does not seem to contain micrometeorites. The outcropping dust can be volcanic material, but as the dark region is several tens of kilometres wide, it represents a period longer that the time of a single big eruption, making a series of several eruptions a more likely cause for the dark region. However, nearby Icelandic volcanoes provide a different REE pattern and are therefore excluded as a possible source. Comparison of the mineralogical composition of the dust with literature values shows that the samples do not contain material from Asian deserts, which is often observed in ice deposited during glacial periods. For these reasons, it is most likely that this dust has a local origin. Coarser grains found at S4 suggest that some recent local wind-blown or basally-entrained material is added at this site. However, as the material from the samples from this site shows the same geochemical composition as the other samples, it confirms the idea that all the investigated dust has a local source. Therefore, the dark region is probably caused by outcropping ice that contain high amounts of local dust, from periods when more dust settled in the accumulation zone of the ice sheet. The amount of dust transport in the tundra of west Greenland is influenced by a lot of complex processes (e.g. Bullard and Austin, 2011) and can change over time. For example, during periods of glacial retreat or during stormy conditions, eolian activity is high. It is likely that during such periods more dust settled on the accumulation zone of the ice sheet, travels through the ice and reaches the ablation zone with the outcropping ice, causing a dark appearance.

In addition, abundant green algae and cyanobacteria, forming cryoconite granules, were observed in the dark region. The relative amount of TOC and therefore organic matter content in this region is much higher than in the area where the reference ice outcrops. This organic matter is likely formed in situ. It is not clear what causes these differences, although global radiation, sediment texture and meltwater supply might play roles. The TOC values found for sediment from the dark region are high compared to literature values. As the organic matter in the cryoconite is known to have a high light absorbency, the dark region is not only caused by dust from the outcropping ice, but biological related processes also contribute to the darkening of the surface.

To find out more about dust from the outcropping ice, large ice cores from several meters below the surface need to be analysed to avoid influence from recent dry or wet deposition. Such cores will also provide quantitative information about the amounts of outcropping dust. Also grain size analyses might reveal information about the origin of the dust. For example, Bøggild et al. (2010) found clay size grains in cryoconite from northeast Greenland, revealing dust from Pleistocene origin. Determining the isotopic composition will contribute to unravel the origin of the dust. Analyses revealing the age of the outcropping ice containing the dust will provide information about the period in which the dust settled on the ice sheet. More investigation on the development 
of microorganisms in the ice could be useful as well. It is likely that higher amounts of dust in the dark region positively influence the absolute amounts of organic matter. Because of their high light absorbency, cyanobacteria and the organic material they produce contribute to the dark colour of the region providing a potentially important positive feedback on the ice melt by enhancing the albedo lowering of the dark region.

Acknowledgements. We thank C. van der Veen, W. Boot, H. Snellen and P. Smeets for their technical support with the field equipment. We are also grateful to D. van der Meent, H. de Waard, A. van Leeuwen, T. Bouten, A. van Dijk and E. van Vilsteren for their help with the geochemical analysis. J. van Tongeren and L. Bik kindly assisted with the optical microscopy. P. Mason and N. Takeuchi are thanked for useful suggestions. D. MacAyeal, M. Stibal, S. Marshall and the anonymous reviewers are thanked for their useful comments that helped to improve the paper. A. Sluijs acknowledges support from the Netherlands Organisation for Scientific Research (NWO-Veni grant 863.07.001) and the European Research Council under the European Community's Seventh Framework Programme (FP7/2007-2013)/ERC Grant agreement no. 259627. Financial support for this work is also provided through the Spinoza-grant and the KNAW-Professorship of J. Oerlemans.

Edited by: S. Marshall

\section{References}

Basile, I., Grousset, F. E., Revel, M., Petit, J. R., Biscaye, P. E., and Barkov, N. I.: Patagonian origin of glacial dust deposited in East Antarctica (Vostok and Dome C) during glacial stages 2, 4 and 6, Earth Planet. Sc. Lett., 146, 573-589, 1997.

Bøggild, C. E., Oerter, H., and Tukiainen, T.: Increased ablation of Wisconsin ice in eastern north Greenland: observations and modelling, Ann. Glaciol., 23, 144-148, 1996.

Bøggild, C. E., Brandt, R. E., Brown, K. J., and Warren, S. G.: The ablation zone in northeast Greenland: ice types, albedos and impurities, J. Glaciol., 56, 101-113, 2010.

Bullard, J. E. and Austin, M. J.: Dust generation on a proglacial floodplain, West Greenland, Aeolian Res., 3, 43-54, 2011.

Clausen, H. B., Hammer, C. U., Hvidberg, C. S., Dahl-Jensen, D., Steffensen, J. P., Kipfstuhl, J., and Legrand, M.: A comparison of the volcanic records over the past 4000 years from the Greenland Ice Core Project and Dye 3 Greenland ice cores, J. Geophys. Res., 102, 26707-26723, 1997.

Fuhrer, K., Wolff, E. W., and Johnsen, S. J.: Timescales for dust variability in the Greenland Ice Core Project (GRIP) ice core in the last 100000 years, J. Geophys. Res., 104, 31043-31052, 1999.

Gajda, R. T.: Cryoconite phenomena on the Greenland ice cap in the Thule area, Can. Geogr., 3, 35-44, 1958.

Greuell, W.: Melt-water accumulation on the surface of the Greenland ice sheet: effect on albedo and mass balance, Geogr. Ann. A, 82, 489-498, 2000.

Gribbon, P. W. F.: Cryoconite holes on Sermikavsak, West Greenland, J. Glaciol., 22, 177-181, 1979.
Hodson, A., Bøggild, C., Hanna, E., Huybrechts, P., Langford, H., Cameron, K., and Houldsworth, A.: The cryoconite ecosystem on the Greenland ice sheet, Ann. Glaciol., 51, 123-129, 2010a.

Hodson, A., Cameron, K., Bøggild, C., Irvinne-Fynn, T., Langford, H., Pearce, D., and Banwart, S.: The structure, biological activity and biogeochemistry of cryoconite aggregates upon an Arctic valley glacier: Longyearbreen, Svalbard, J. Glaciol., 56, 349361, 2010b.

Knap, W. H. and Oerlemans, J.: The surface albedo of the Greenland ice sheet: satellite-derived and in situ measurements in the Søndre Strømfjord area during the 1991 melt season, J. Glaciol., 42, 364-374, 1996.

Konzelmann, T., Van de Wal, R. S. W., Greuell, W., Bintanja, R., Henneken, E. A. C., and Abe-Ouchi, A.: Parameterization of global and longwave incoming radiation for the Greenland Ice Sheet, Global Planet. Change, 9, 143-164, 1994.

Langford, H., Hodson, A., Banwart, S., and Bøggild, C.: The microstructure and biogeochemistry of Arctic cryoconite granules, Ann. Glaciol., 51, 87-94, 2010.

Maggi, V.: Mineralogy of atmospheric microparticles deposited along the Greenland Ice Core Project ice core, J. Geophys. Res., 102, 26725-26734, 1997.

Mahaney, W. C.: Atlas of sand grain surfae textures and applications, Oxford University Press, Oxford, United Kingdom, 2002.

Maurette, M., Jéhanno, C., Robin, E., and Hammer, C.: Characteristics and mass distribution of extraterrestrial dust from the Greenland ice cap, Nature, 328, 699-702, 1987.

Mortensen, A. K., Bigler, M., Grönvold, K., Steffensen, J. P., and Johnsen, S. J.: Volcanic ash layers from the Last Glacial Termination in the NGRIP ice core, J. Quaternary Sci., 20, 209-219, 2005.

Moune, S., Gauthier, P. J., Gislason, S. R., and Sigmarsson, O.: Trace element degassing and enrichment in the eruptive plume of the 2000 eruption of Hekla volcano, Iceland, Geochim. Cosmochim. Ac., 70, 461-479, 2006.

Nieuwenhuize, J., Maas, Y. E. M., and Middelburg, J. J.: Rapid analysis of organic carbon and nitrogen in particulate materials, Mar. Chem., 45, 217-224, 1994.

Nordenskjöld, N. E.: Account of an Expedition to Greenland in the year 1870, Geol. Mag., 9, 355-368, 1872.

Nriagu, J. O. and Pacyna, J. M.: Quantitative assessment of worldwide contamination of air, water and soils by trace metals, Nature, 333, 134-139, 1988.

Oerlemans, J. and Vugts, H. F.: A meteorological experiment in the melting zone of the Greenland ice sheet, B. Am. Meteorol. Soc., 74, 355-365, 1993.

Petrenko, V. V., Severinghaus, J. P., Brook, E. J., Reeh, N., and Schaefer, H.: Gas records from the West Greenland ice margin covering the Last Glacial Termination: a horizontal ice core, Quaternary Sci. Rev., 25, 865-875, 2005.

Reeh, N., Thomsen, H. H., and Clausen, H. B.: The Greenland icesheet margin - a mine of ice for paleo-environmental studies, Palaeogeogr. Palaeoclimatol. Palaeocol., 58, 229-234, 1987.

Reeh, N., Oerter, H., and Thomsen, H. H.: Comparison between Greenland ice-margin and ice-core oxygen-18 records, Ann. Glaciol., 35, 136-144, 2002.

Ruth, U., Wagenbach, D., Steffensen, J. P., and Bigler, M.: Continuous record of microparticle concentration and size distribution in the central Greenland NGRIP ice core 
during the last glacial period, J. Geophys. Res., 108, 4098, doi:10.1029/2002JD002376, 2003.

Stibal, M., S̆abacká, M., and Kaštovská, K.: Microbial Communities on Glacier Surfaces in Svalbard: Impact of physical and chemical properties on abundance and structure of cyanobacteria and algae, Microb. Ecol., 52, 644-654, 2006.

Stibal, M., Lawson, E. C., Lis, G. P., Mak, K. M., Wadham, J. L., and Anesio, A. M.: Organic matter content and quality in supraglacial debris across the ablation zone of the Greenland ice sheet, Ann. Glaciol., 51, 1-8, 2010.

Svensson, A., Biscaye, P. E., and Grousset, F. E.: Characterization of late glacial continental dust in the Greenland Ice Core Project ice core, J. Geophys. Res., 105, 4637-4656, 2000.

Takeuchi, N.: The altitudinal distribution of snow algae on an Alaska glacier (Gulkana Glacier in the Alaska Range), Hydrol. Process., 15, 3447-3459, 2001.

Takeuchi, N.: Optical characteristics of cryoconite (surface dust) on glaciers: the relationship between light absorbency and the property of organic matter contained in the cryoconite, Ann. Glaciol., 34, 409-414, 2002.

Takeuchi, N.: Temporal and spatial variations in spectral reflectance and characteristics of surface dust on Gulkana Glacier, Alaska Range, J. Glaciol., 55, 701-709, 2009.

Takeuchi, N., Kohshima, S., and Seko, K.: Structure, formation, and darkening process of albedo reducing material (cryoconite) on a Himalayan glacier: a granular algal mat growing on the glacier, Arct. Antarct. Alp. Res., 33, 115-122, 2001.

Taylor, S. R. and McLennan, S. M.: The geochemical evolution of the continental crust, Rev. Geophys., 33, 241-265, 1995.

Uetake, J., Naganuma, T., Hebsgaard, M. B., Kanda, H., and Kohshima, S.: Communities of algae and cyanobacteria on glaciers in west Greenland, Polar Sci., 4, 71-80, 2010.
Van de Wal, R. S. W. and Oerlemans, J.: An energy balance model for the Greenland ice sheet, Global Planet. Change, 9, 115-131, 1994.

Van de Wal, R. S. W., Greuell, W., Van den Broeke, M. R., Reijmer, C. H., and Oerlemans, J.: Surface mass-balance observations and automatic weather station data along a transect near Kangerlussuaq, West Greenland, Ann. Glaciol., 42, 311-316, 2005.

Van de Wal, R. S. W., Boot, W., Van den Broeke, M. R., Smeets, C. J. P. P., Reijmer, C. H., Donker, J. J. A., and Oerlemans, J.: Large and rapid melt-induced velocity changes in the ablation zone of the Greenland ice sheet, Science, 321, 111-113, 2008.

Van den Broeke, M., Smeets, P., Ettema, J., Van der Veen, C., Van de Wal, R., and Oerlemans, J.: Partitioning of melt energy and meltwater fluxes in the ablation zone of the west Greenland ice sheet, The Cryosphere, 2, 179-189, doi:10.5194/tc-2-179-2008, 2008.

Wharton, R. A., McKay, C. P., Simmons, G. M., and Parker, B. C.: Cryoconite holes on glaciers, BioScience, 35, 499-503, 1985.

Wientjes, I. G. M. and Oerlemans, J.: An explanation for the dark region in the western melt zone of the Greenland ice sheet, The Cryosphere, 4, 261-268, doi:10.5194/tc-4-261-2010, 2010.

Yallop, M. L. and Anesio, A. M.: Benthic diatom flora in supraglacial habitats: a generic-level comparison, Ann. Glaciol., 51, 15-22, 2010.

Yde, J. C., Finster, K. W., Raiswell, R., Steffensen, J. P., Heinemeier, J., Olsen, J., Gunnlaugsson, H. P., and Nielsen, O. B.: Basal ice microbiology at the margin of the Greenland ice sheet, Ann. Glaciol., 51, 71-79, 2010. 